\title{
A Study on the Preparation of Regular Multiple Micro-Electrolysis Filler and the Application in Pretreatment of Oil Refinery Wastewater
}

\author{
Ruihong Yang ${ }^{1,2}$, Jianzhong ZHU ${ }^{1, *}$, Yingliu Li $^{1}$ and Hui Zhang ${ }^{1}$ \\ 1 Key Laboratory for Integrated Regulation and Resource Development on Shallow Lake of Ministry of \\ Education, College of Environment, Hohai University, Nanjing 210098, China; rhyang123@126.com (R.Y.); \\ liyingliu@em.jpu.edu.cn (Y.L.); zhhhhz1@gmail.com (H.Z.) \\ 2 Department of Chemical Engineering, Yangzhou Polytechnic Institute, Yangzhou 225127, China \\ * Correspondence: zhuhhai2010@hhu.edu.cn; Tel.: +86-137-3918-6298
}

Academic Editors: Rao Bhamidiammarri and Kiran Tota-Maharaj

Received: 3 March 2016; Accepted: 19 April 2016; Published: 29 April 2016

\begin{abstract}
Through a variety of material screening experiments, $\mathrm{Al}$ was selected as the added metal and constituted a multiple micro-electrolysis system of $\mathrm{Fe} / \mathrm{C} / \mathrm{Al}$. The metal proportion of alloy-structured filler was also analyzed with the best $\mathrm{Fe} / \mathrm{C} / \mathrm{Al}$ ratio of 3:1:1. The regular $\mathrm{Fe} / \mathrm{C} / \mathrm{Al}$ multiple micro-electrolysis fillers were prepared using a high-temperature anaerobic roasting method. The optimum conditions for oil refinery wastewater treated by $\mathrm{Fe} / \mathrm{C} / \mathrm{Al}$ multiple micro-electrolysis were determined to be an initial $\mathrm{pH}$ value of 3, reaction time of $80 \mathrm{~min}$, and $0.05 \mathrm{~mol} / \mathrm{L} \mathrm{Na}_{2} \mathrm{SO}_{4}$ additive concentration. The reaction mechanism of the treatment of oil refinery wastewater by $\mathrm{Fe} / \mathrm{C} / \mathrm{Al}$ micro-electrolysis was investigated. The process of the treatment of oil refinery wastewater with multiple micro-electrolysis conforms to the third-order reaction kinetics. The gas chromatography-mass spectrometry (GC-MS) used to analyze the organic compounds of the oil refinery wastewater before and after treatment and the Ultraviolet-visible spectroscopy (UV-VIS) absorption spectrum analyzed the degradation process of organic compounds in oil refinery wastewater. The treatment effect of $\mathrm{Fe} / \mathrm{C} / \mathrm{Al}$ multiple micro-electrolysis was examined in the continuous experiment under the optimum conditions, which showed high organic compound removal and stable treatment efficiency.
\end{abstract}

Keywords: micro-electrolysis; fillers; preparation; oil refinery wastewater

\section{Introduction}

Oil refinery wastewater is one of the major forms of industrial wastewater, mainly coming from oil refining units, including dewatering and desalting in electric dewatering plants, direct distillation of crude oil, and cracking and distillation of heavy oil. Some fraction is a collection of slick oil, emulsified oil, dissolving organic matter, and salt in the integration of a multiphase system, with high oil content, high $\mathrm{COD}$ content, $\mathrm{BOD}_{5}$, sulfide, volatile phenol, suspended solids, and ammonia, nitrogen, etc. [1,2]. Oil refining wastewater treatment technology can be divided into physical, chemical, biological, and physicochemical treatment. Physical treatment includes gravity settling methods, flotation, filtration methods, hydro-cyclone separation, etc. Chemical treatment includes coagulation methods, advanced oxidation technologies, and coarse graining technology, etc. Biochemical methods mainly include the biochemical tower, biological filter, MBR, AO process, etc. [3-5]. Physical and chemical methods have adsorption, membrane separation, magnetic separation technologies, and electrochemistry methods, etc. [6-9]. Several innovative technologies for oil refining wastewater treatment emerged, such as ultrasound and dispersed nanoscale zero-valent 
iron particle coupling techniques [10]; Liu et al. used a gas-liquid-solid three-phase flow airlift loop bioreactor to treat oil refinery wastewater [11]; Shariati et al. have reported membrane sequencing batch reactors and the effect of hydraulic retention time on the performance and fouling characteristics of membrane sequencing batch reactors was researched [12]; Carlos et al. used coagulation-flocculation and flotation coupling techniques to treat petroleum refinery effluent, and the optimization of coagulation-flocculation and flotation parameters were obtained [13]; a three-dimensional electrode reactor was used to pretreat heavy oil refinery wastewater by Wei et al. [14]; Saien treated oil refinery wastewater with photo-catalytic degradation technology under mild conditions [15].

At present, the process of "oil separator-air flotation-biological" is the most common process applied in domestic refining wastewater treatment. Outside drainage in most refining enterprises could attain national standards. However, with the increasingly serious situation of environmental protection and strict pollution discharge standards, the common process has been difficult to meet the requirement of the drainage standard and the common process need to be reinforced. Nowadays the main research direction is to enhance pretreatment units before the biochemical system, such as removing part of the refractory organic matter, reducing the organic load of the biochemical system, improving the wastewater biochemical performance, and strengthening the system through advanced oxidation techniques [16,17].

Micro-electrolysis technology is a simple and effective electrochemical oxidation technolog, also called internal micro-electrolysis, the iron reduction method, zero-valent iron, etc. It was introduced to China in the 1980s, obtained the favor of experts and scholars, and it has been widely used in dyeing, chemical, pharmaceutical, coking, and other industrial wastewater treatment [18-21]. The principle is applied in the potential difference between iron and carbon particles, iron with low potential anodes, and carbon with the high potential cathodes. Iron and carbon in the electrolyte solution form countless macro-galvanic cells. Electrochemical reactions can cause flocculation, precipitation, adsorption, bridging, electroplating, and other synergies [16]. In recent years, the research and application of micro-electrolysis technology in refractory biodegradable organic wastewater treatment at home and abroad was popular. $\mathrm{Fe} / \mathrm{C}$ micro-electrolysis was applied in denitrification for the coking wastewater [22,23]; Lai et al. applied micro-electrolysis to treat wastewater from acrylonitrile-butadiene-styrene (ABS) resin manufacturing [24]; Yang et al. have discussed the mechanism, kinetics and application of interior micro-electrolysis on enhanced activated sludge [25]; an internal electrolysis filter was also applied in mixed chemical wastewater treatment $[26,27]$. Nowadays, many scholars combine micro-electrolysis with other techniques to treat the refractory organic wastewater. Huang et al. applied anaerobic treatment coupled with micro-electrolysis (ATCM) in the treatment of anthraquinone dye wastewater [28]; Qin et al. applied micro-electrolysis coupled with the membrane bio-reactor (MBR) process in treatment of anthraquinone dye wastewater [29].

The traditional Fe/C micro-electrolysis uses an iron and activated carbon physical mixture as filler; the reaction efficiency is low and has engineering problems, such as easy blocking, hardening, and deactivation during application, which has severe limitations for large-scale applications [30]. Aimed to improve the reaction efficiency and solve the practical problems in the application of micro-electrolysis technology, we attempted to develop more efficient metal alloy-structured regular multiple micro-electrolysis fillers. Then, the regular multiple micro-electrolysis filler was applied in oil refinery wastewater treatment by batch experiments to explore the influence factors of multiple micro-electrolysis. The effect of micro-electrolysis in oil refinery wastewater treatment and the change of filler after a long continuously-running time were studied by continuous experiments.

\section{Materials and Analytical Methods}

\subsection{Materials}

Iron powders include iron over $98.0 \%$ (analytically pure); activated carbon powder (analytically pure); aluminum powders include aluminum over $99.0 \%$ (analytically pure); nickel powders include 
nickel over 99.5\% (analytically pure); copper powders include copper over 99.5\% (analytically pure); $\mathrm{CH}_{2} \mathrm{Cl}_{2}$ (analytically pure); and the correlative reagents for $\mathrm{COD}, \mathrm{BOD}_{5}$, and $\mathrm{pH}$ determined. The wastewater was the effluent of a primary flotation tank obtained from a wastewater treatment plant of a refinery in China, the characteristics are shown in Table 1.

Table 1. Characteristics of oil refinery wastewater.

\begin{tabular}{cccccc}
\hline Index & COD $(\mathrm{mg} / \mathrm{L})$ & BOD $_{5}(\mathrm{mg} / \mathrm{L})$ & $\mathrm{NH}_{3}-\mathrm{H}(\mathrm{mg} / \mathrm{L})$ & Oil $(\mathrm{mg} / \mathrm{L})$ & $\mathrm{pH}$ \\
\hline Value & $340-430$ & $76-95$ & $7-15$ & $32-48$ & $6-8$ \\
\hline
\end{tabular}

\subsection{Analysis Methods}

The $\mathrm{COD}$ and $\mathrm{BOD}_{5}$ were determined to use the COD analyzer (COD-571, Rex, Shanghai, China) and $\mathrm{BOD}_{5}$ analyzer (LB-50, LOOBO, Qingdao, China), respectively. The $\mathrm{BOD}_{5} / \mathrm{COD}$ index $(\mathrm{B} / \mathrm{C})$ was used to assess the wastewater biodegradability. The $\mathrm{pH}$ was measured by $\mathrm{pHS}-3 \mathrm{C}$ meter (Rex, Shanghai, China). $\mathrm{NH}_{3}-\mathrm{N}$ of the samples was determined according to standard methods [31]. The oil concentration was measured by ultraviolet spectrophotometer (UV-1801) (Benifen-Ruili, Beijing, China). The ultraviolet absorption spectrum scanned by ultraviolet spectrophotometer (UV-1801). The UV-VIS absorption spectrum of the oil refinery wastewater carried out in $10 \mathrm{~mm}$ quartz cuvettes and the UV-VIS spectra were recorded from 190 to $400 \mathrm{~nm}$ using deionized water as a blank. The morphology of fillers before and after use were characterized by a S-4800 II FE-SEM field emission scanning electron microscope (FE-SEM, $30 \mathrm{kV}$, Hitachi, Tokyo, Japan). GC-MS was used for organic compounds analysis. Prior to GC-MS determination, a $1000 \mathrm{~mL}$ sample was extracted using $20 \mathrm{~mL} \mathrm{CH}_{2} \mathrm{Cl}_{2}$ three times under acidic conditions and three times under alkaline conditions, respectively. The six extracted layers were mixed, dehydrated, with anhydrous sodium sulfate and dried with the aid of a nitrogen flow. The residue was dissolved in $1.0 \mathrm{~mL} \mathrm{CH}_{2} \mathrm{Cl}_{2}$ and $1 \mu \mathrm{L}$ was injected into a Trace DSQ II GC-MS system (Thermo Electron, Massachusetts, USA) equipped with a DB-5 capillary column with an inner diameter of $0.25 \mathrm{~mm}$ and $30.0 \mathrm{~m}$ in length, vaporization temperature of $280^{\circ} \mathrm{C}$, and separator temperature of $280^{\circ} \mathrm{C}$. The GC column was operated in temperature-programmed mode at $80^{\circ} \mathrm{C}$ for $10 \mathrm{~min}$, raised at $5^{\circ} \mathrm{C} \cdot \mathrm{min}^{-1}$ to $140{ }^{\circ} \mathrm{C}$ (held for $2 \mathrm{~min}$ ), and then raised at $5^{\circ} \mathrm{C} \cdot \mathrm{min}^{-1}$ to $280{ }^{\circ} \mathrm{C}$ (held for $10 \mathrm{~min}$ ). Carrier gas was $\mathrm{He}$, the pre-column pressure was $10 \mathrm{pa}$, split ratio 10:1, the sample quantity was $1 \mu \mathrm{L}$. EI mass spectrometry ionization mode, electron bombardment energy $70 \mathrm{eV}$, electron multiplier voltage $1145 \mathrm{~V}$, the ion source temperature was $140{ }^{\circ} \mathrm{C}$, the scanning time was $1 \mathrm{~s}$, and the quality range of 50-500 amu. Analysis was undertaken with reference to the NIST 05 mass spectral library database. Quantitative analysis used the peak area normalization method [32].

The COD removal rate at any distillation time $t, R_{C O D}$ was calculated through Equation (1):

$$
R_{C O D}=\frac{\left(C_{0}-C_{t}\right)}{C_{0}} \times 100 \%
$$

where $C_{0}$ is the initial COD value of raw wastewater and $C_{t}$ is the concentration of COD of the effluents at any time $t$.

\subsection{Experimental Setup}

\subsubsection{Experimental Method}

(1) Iron and activated carbon pretreatment. The iron powder was soaked for $10 \mathrm{~min}$ in the mass fraction of $5 \%$ dilute sulfuric acid to remove the surface oxide layer, washed with $\mathrm{NaOH}$ solution for $10 \mathrm{~min}$, and rinsed clean with distilled water. The activated carbon was soaked for $24 \mathrm{~h}$ in the raw water to establish the pollutant adsorption saturation.

(2) Determination of the added metal type and proportion. $300 \mathrm{~mL}$ of oil refinery wastewater was mixed with $200 \mathrm{~g}$ filler (mass ratio of $\mathrm{Fe} / \mathrm{C}$ was 2:1; mass ratio of $\mathrm{Fe} / \mathrm{C} /$ added metal was 2:1:1, 
ingredients of filler were physically mixed). The reaction mixtures were incubated at $\mathrm{pH} 3$ for $60 \mathrm{~min}$. $\mathrm{NaOH}$ was added into saved supernatants to adjust $\mathrm{pH}$ to $c a$. 9-10. After sedimentation and filtration processes, COD values were measured.

(3) Preparation of regular multiple micro-electrolytic filler. The regular multiple micro-electrolysis filler with a metal alloy structure and includes iron powder, activated carbon, and other metal catalysts. The preparation process of regular multiple micro-electrolysis filler includes the following steps: first, iron powder, activated carbon, metal catalyst, and bentonite are mixed in proportion (Fe/ $\mathrm{Al} / \mathrm{C}$ is 3:1:1 and bentonite $15 \%$, the proportion and ingredients are determined by the following experiment) and a certain amount of distilled water was added to the mixture. Second, the mixture was granulated and shaped. Third, the mixture was cured anaerobically under nitrogen at $x^{\circ} \mathrm{C}$ for $4 \mathrm{~h}$. Fourth, the sample was roasted under nitrogen for $4 \mathrm{~h}$ at $1000-1100{ }^{\circ} \mathrm{C}$ temperature, followed by subsequent cooling to room temperature and storing under nitrogen.

(4) Pretreatment of homemade regular multiple micro-electrolysis filler. The filler was soaked two hours in the mass fraction of $5 \%$ dilute sulfuric acid to remove the surface oxide layer, rinsed clean with distilled water; then, the filler was soaked two hours in the raw water to establish the pollutant adsorption saturation.

(5) Influence factors. Under the condition of the $\mathrm{pH}$ of acid, $300 \mathrm{~mL}$ oil refinery wastewater was reacted with $200 \mathrm{~g}$ homemade regular $\mathrm{Fe} / \mathrm{C} / \mathrm{Al}$ multiple micro-electrolysis filler for $100 \mathrm{~min}$, supernatants were taken and their $\mathrm{pH}$ adjusted to $c a$. 9-10 with $\mathrm{NaOH}$, then sedimentation and filtration was performed, and the COD values were measured.

(6) Continuous experiment. Adjust $\mathrm{pH}$ of raw water to the acid inlet of the reactor, which was filled with the pretreated homemade regular multiple micro-electrolysis filler, took a certain amount of water in the sampling mouth at a certain time, with $\mathrm{NaOH}$ adjusted the $\mathrm{pH}$ to $c a$. 9-10, then sedimentation and filtration was performed, and the $\mathrm{COD}, \mathrm{NH}_{3}-\mathrm{N}$, oil, and $\mathrm{BOD}_{5}$ values were determined.

\subsubsection{Experimental Apparatus}

The beaker batch experiments were used to study the influence factors of multiple micro-electrolysis. A continuous experiment was used to study the application of multiple micro-electrolysis. The device is shown in Figure 1. The reactor was made of a transparent synthetic glass column. The experimental apparatus is a cylindrical micro-electrolysis reactor $(\varnothing 10 \mathrm{~cm} \times 30 \mathrm{~cm})$, the effective volume is about $2.0 \mathrm{~L}$.

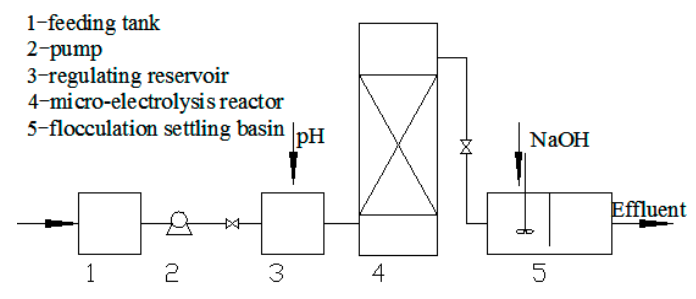

Figure 1. Continuous micro-electrolysis reactor.

\section{Results and Discussion}

\subsection{Materials Selection and Formula Test}

The main ingredients of regular multiple micro-electrolysis fillers included iron, activated carbon, and additional metal. The key of the experiment was to select an additional metal type and determine the formula.

\subsubsection{The Types of Metal Catalysts Added}

On the basis of traditional $\mathrm{Fe} / \mathrm{C}$ micro-electrolysis, we added different kinds of metal catalysts such as $\mathrm{Al}, \mathrm{Cu}$, and $\mathrm{Ni}$ to constitute multiple micro-electrolysis systems to treat oil refinery wastewater. 
Through study of the treatment effect of multiple micro-electrolysis system, a suitable metal catalyst for oil refinery wastewater treatment was selected. The $\mathrm{m}(\mathrm{Fe} / \mathrm{C})$ was $2: 1 ; \mathrm{m}(\mathrm{Fe} / \mathrm{C} /$ adding metal $)$ was 2:1:1, $\mathrm{pH}$ were $1,3,5,7,9$, and 11 , and a reaction time of $60 \mathrm{~min}$. The experimental results are shown in Figure 2.

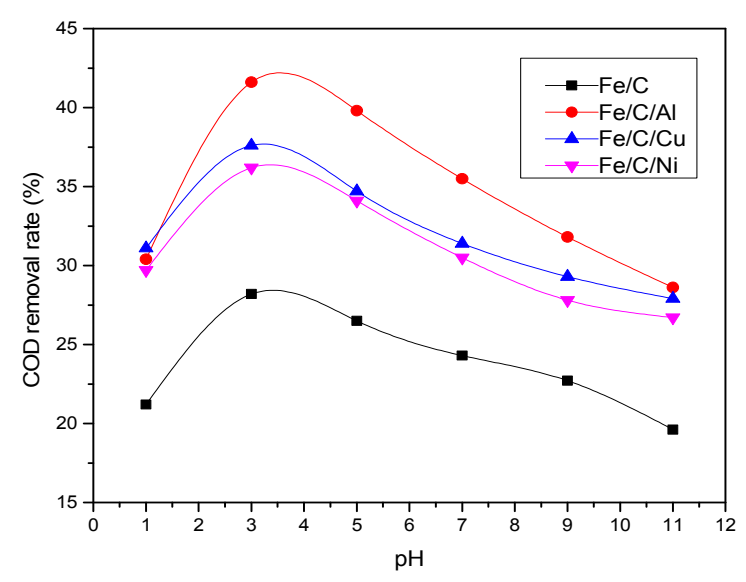

Figure 2. Influence of different metal catalysts on COD removal rate.

Figure 2 showed, on the basis of the $\mathrm{Fe} / \mathrm{C}$ system, added $\mathrm{Cu}, \mathrm{Ni}$, and $\mathrm{Al}$ to constitute the multiple micro-electrolysis system, respectively, which had an obvious difference in COD removal effects. The maximum COD removal rate of the $\mathrm{Fe} / \mathrm{C} / \mathrm{Cu}$ system was $37.6 \%$, $\mathrm{Fe} / \mathrm{C} / \mathrm{Ni}$ system was $36.2 \%$, and $\mathrm{Fe} / \mathrm{C} / \mathrm{Al}$ system was $41.6 \%$. Visibly, the COD removal rates of all $\mathrm{Fe} / \mathrm{C} / \mathrm{Cu}, \mathrm{Fe} / \mathrm{C} / \mathrm{Ni}$, and $\mathrm{Fe} / \mathrm{C} / \mathrm{Al}$ systems were higher than the $\mathrm{Fe} / \mathrm{C}$ system. Hence, adding $\mathrm{Cu}, \mathrm{Ni}$, and $\mathrm{Al}$ all has certain catalytic effects on micro-electrolysis. The highest COD removal rate was the $\mathrm{Fe} / \mathrm{C} / \mathrm{Al}$ system, so $\mathrm{Al}$ had the most obvious micro-electrolysis catalytic effect. $\mathrm{Al}$ was selected to be added to enhance the $\mathrm{Fe} / \mathrm{C}$ micro-electrolysis system, constituting a Fe/C/Al multiple micro-electrolysis system. In addition, aimed at different kinds of wastewater, the choice of added metal catalyst types was different, and experiments were needed to determine the composition of effective components.

\subsubsection{Filler Formula Experiment}

(1) $\mathrm{m}(\mathrm{Fe} / \mathrm{C})$ proportioning experiment. Under the condition of $\mathrm{pH} 3$, and $60 \mathrm{~min}$ reaction time, $\mathrm{Fe} / \mathrm{C}$ micro-electrolysis on the COD removal rate is shown in Figure 3.

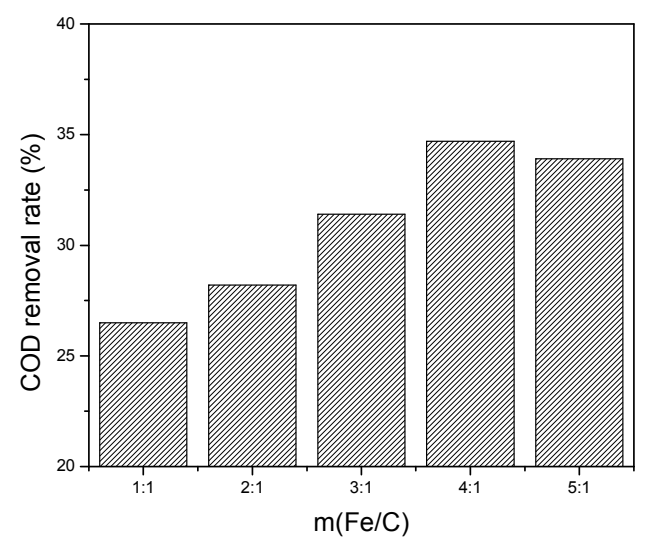

Figure 3. Influence of $\mathrm{m}(\mathrm{Fe} / \mathrm{C})$ on the COD removal rate.

As shown in Figure 3, the COD removal rate reached a maximum of $34.7 \%$ when the $\mathrm{m}(\mathrm{Fe} / \mathrm{C})$ was 4:1. When the $\mathrm{m}(\mathrm{Fe} / \mathrm{C})$ was $4: 1$, the molar ratio was close to $1: 1$, it could constitute the highest number 
of micro-batteries in the micro-electrolysis system. When iron was deficient, it could not form enough micro-batteries, so the electrode reaction rate dropped, and COD removal rate would be low. When iron was in excess, the iron directly reacted with $\mathrm{H}^{+}$to generate $\mathrm{H}_{2}$ and $\mathrm{Fe}^{2+}$, so it would generate less new ecological $(\mathrm{H})$, the redox ability was weak, and the COD removal rate decreased. So, the reasonable $\mathrm{m}(\mathrm{Fe} / \mathrm{C})$ was $4: 1$ when refining wastewater treatment by micro-electrolysis.

(2) $\mathrm{m}(\mathrm{Fe} / \mathrm{C} / \mathrm{Al})$ proportioning experiment. Next, we discussed the influence of $\mathrm{m}(\mathrm{Fe} / \mathrm{C} / \mathrm{Al})$ on treatment efficiency in micro-electrolysis. The $\mathrm{pH}$ was $3-4$, the $\mathrm{m}(\mathrm{Fe} / \mathrm{C} / \mathrm{Al})$ were 1:1:1, 2:1:1, 3:1:1, and 4:1:1, respectively, and the reaction time was $60 \mathrm{~min}$. Influence of $\mathrm{m}(\mathrm{Fe} / \mathrm{C} / \mathrm{Al})$ on micro-electrolysis treatment effect is shown in Figure 4.

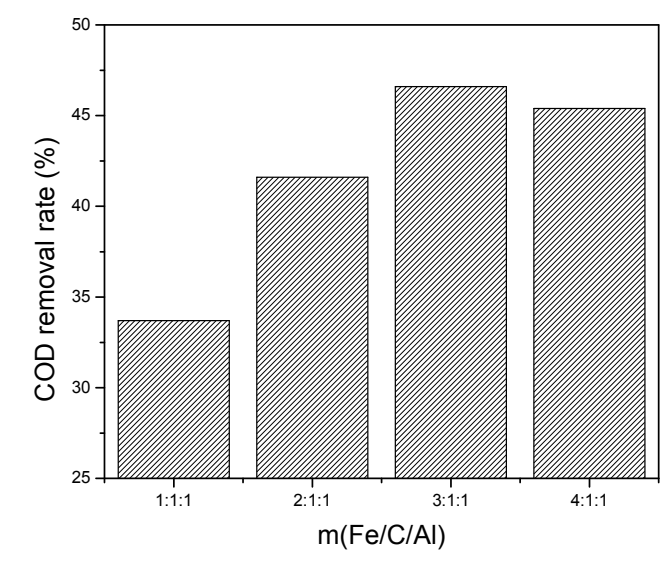

Figure 4. Influence of $\mathrm{m}(\mathrm{Fe} / \mathrm{C} / \mathrm{Al})$ on the $\mathrm{COD}$ removal rate.

From Figure 4, the influence of different $\mathrm{m}(\mathrm{Fe} / \mathrm{C} / \mathrm{Al})$ on COD removal efficiency was obvious. When $\mathrm{m}(\mathrm{Fe} / \mathrm{C} / \mathrm{Al})$ was 3:1:1, COD removal rate increased up to $46.6 \%$. The results indicated that the optimum $\mathrm{m}(\mathrm{Fe} / \mathrm{C} / \mathrm{Al})$ was 3:1:1 as the ratio of active ingredients of filler.

\subsubsection{The Physical and Chemical Characteristics of Multiple Micro-Electrolysis Filler}

Regular filler was made by a high-temperature anaerobic roasting method as shown in Figure 5. It was sintered, forming a porous alloy spherical structure by reducing iron, aluminum, bentonite, and activated carbon. The bulk density of the filler was $1000-1100 \mathrm{~kg} / \mathrm{m}^{3}$, porosity was $68 \%$, specific surface area over $1.4 \mathrm{~m}^{2} / \mathrm{g}$, and the size was $10 \mathrm{~mm}$ in diameter.

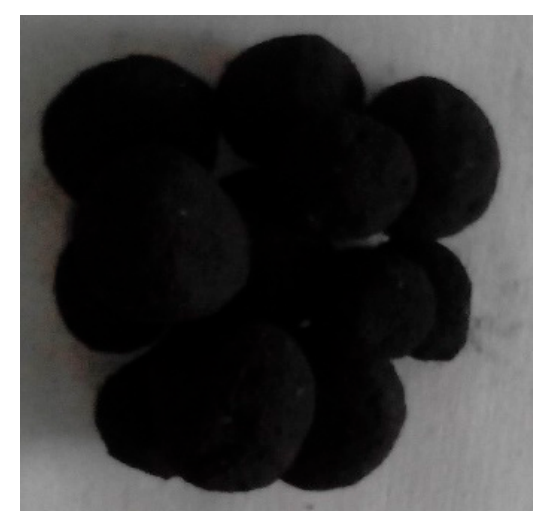

Figure 5. Shape of homemade regular $\mathrm{Fe} / \mathrm{C} / \mathrm{Al}$ multiple micro-electrolysis filler. 


\subsection{Influence Factors}

\subsubsection{Influence of Initial $\mathrm{pH}$ value}

These experiments were mainly to investigate micro-electrolysis treatment effects under different initial $\mathrm{pH}$ value conditions. The $\mathrm{pH}$ was $3,5,7,9$, and 11 , respectively, and the reaction time was $100 \mathrm{~min}$. The experimental results are shown in Figure 6.

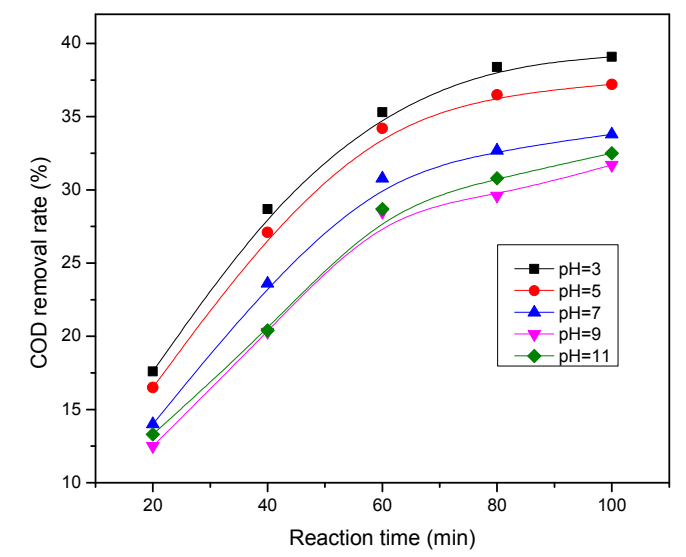

Figure 6. Influence of initial $\mathrm{pH}$ value on the COD removal rate.

Figure 6 showed the treatment effect was significantly different under the different initial $\mathrm{pH}$ values. When $\mathrm{pH}$ was 3 , the COD removal rate was $39.1 \%$ after reacting for $100 \mathrm{~min}$. The treatment effect significantly reduced with the increase of $\mathrm{pH}$ value when the $\mathrm{pH}$ exceeded 3 . In solution with low $\mathrm{pH}$, the galvanic cell reaction could be high, the anodic reaction produced new ecosystem bivalent iron, and the cathode produced new ecosystem $(\mathrm{H})$, which could degrade many organic compounds in wastewater under acidic conditions. When $\mathrm{pH}$ was too low, the iron ion acid dissolution dominated, the electrochemical dissolution was less, and large amounts of hydrogen were produced quickly and reacted with the iron. The degradation of organic compounds generally occurred on the iron surface, thus hindering the organic pollutants' contact with the solid surface. Under high $\mathrm{pH}$ conditions, iron and aluminum ions generated a complex which attached to the surface of the filler and hindered the efforts of the micro-electrolysis reaction [20]. Thus, the most proper $\mathrm{pH}$ value of multiple micro-electrolysis reaction was 3.

\subsubsection{Influence of Auxiliary Electrolyte Dosing}

This experiment was mainly to investigate the influence of auxiliary electrolyte dosing on the treatment effect. The $\mathrm{pH}$ was 3 , auxiliary electrolyte $\mathrm{Na}_{2} \mathrm{SO}_{4}$ additive concentration was $0.02,0.03$, $0.04,0.05$, and $0.06 \mathrm{~mol} / \mathrm{L}$, respectively, and the reaction time was $100 \mathrm{~min}$. The experiment results are shown in Figure 7.

As Figure 7 shows, the COD removal rate was improved when $\mathrm{Na}_{2} \mathrm{SO}_{4}$ was added as the auxiliary electrolyte to the reaction system with different concentrations. When the concentration of $\mathrm{Na}_{2} \mathrm{SO}_{4}$ was less than $0.05 \mathrm{~mol} / \mathrm{L}$, the COD removal rate of oil refinery wastewater increased with the increase of auxiliary electrolyte $\mathrm{Na}_{2} \mathrm{SO}_{4}$ concentration. When $\mathrm{Na}_{2} \mathrm{SO}_{4}$ concentration was $0.05 \mathrm{~mol} / \mathrm{L}$, the COD removal rate reached $42.5 \%$ after 100 min incubation, while continuously increasing the concentration of the auxiliary electrolytes would not significantly boost the processing efficiency. The main reason was the electrical conductivity of the reaction system which was improved with the increase of auxiliary electrolyte concentration. It enhanced the mass transfer rate and promoted the micro-electrolysis degradation of wastewater better [28]. 


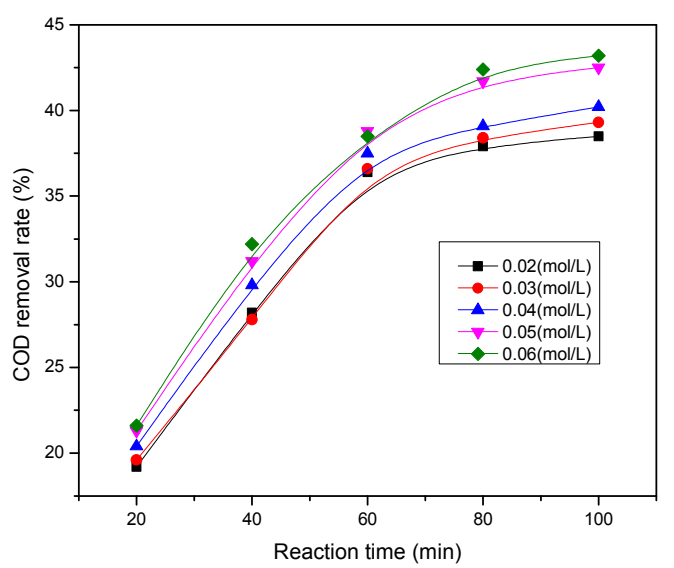

Figure 7. Influence of the concentration of auxiliary electrolyte on the COD removal rate.

\subsection{The Comprehensive Treatment Effect under the Optimal Conditions}

This experiment mainly studied the comprehensive treatment effect of refining wastewater treated by multiple micro-electrolysis technology under the optimum process conditions. The three major indicators, $\mathrm{COD}, \mathrm{NH}_{3}-\mathrm{N}$, and oil removal rate, were mainly investigated. The results are shown in Figure 8.

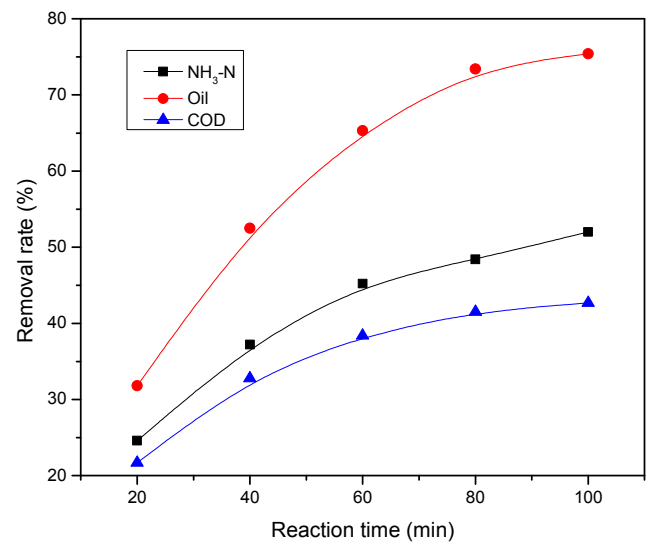

Figure 8. The comprehensive treatment effect under the optimum condition.

As Figure 8 shows, the treatment effect gradually improved with the extension of the reaction time. When the reaction time reached $80 \mathrm{~min}$, the removal rate of COD was $41.5 \%, \mathrm{NH}_{3}-\mathrm{N} 48.4 \%$, and oil $73.4 \%$. When the reaction time was continuously extended, the treatment effect had no significant improvement. The micro-electrolysis reaction would be fuller with a longer reaction time, but since the reaction progressed, $\mathrm{H}^{+}$was consumed. If the $\mathrm{H}^{+}$concentration reduced, the reaction rate significantly decreased and the reaction eventually stopped. Thus, there was no sense in prolonging the reaction time after $80 \mathrm{~min}$.

\subsection{Reaction Kinetics Study}

The multiple micro-electrolysis reaction was carried out under the optimum reaction conditions. The COD values of refining wastewater were measured at the reaction time of $0,20,40,60,80,100$, and $120 \mathrm{~min}$, respectively. The experiment results are shown in Table 2.

The treatment process of oil refinery wastewater was fitted by zero-order, first order, second-order, and third-order reaction kinetics based on the data of Table 2, respectively. The various levels reaction kinetics equations are obtained as indicated in Table 3. 
Table 2. The concentration of COD of oil refinery wastewater at different times.

\begin{tabular}{cccccccc}
\hline $\mathbf{t} / \mathbf{m i n}$ & $\mathbf{0}$ & $\mathbf{2 0}$ & $\mathbf{4 0}$ & $\mathbf{6 0}$ & $\mathbf{8 0}$ & $\mathbf{1 0 0}$ & $\mathbf{1 2 0}$ \\
\hline $\mathrm{C}(\mathrm{g} / \mathrm{L})$ & 0.365 & 0.287 & 0.253 & 0.235 & 0.216 & 0.208 & 0.201 \\
$\ln C$ & -1.008 & -1.248 & -1.374 & -1.448 & -1.532 & -1.570 & -1.604 \\
$1 / \mathrm{C}$ & 2.739 & 3.484 & 3.953 & 4.255 & 4.629 & 4.808 & 4.975 \\
$1 / \mathrm{C}^{2}$ & 7.506 & 12.140 & 15.623 & 18.108 & 21.433 & 23.114 & 24.752 \\
\hline
\end{tabular}

Table 3. Equation of reaction kinetics for multiple micro-electrolysis degrading COD of oil refinery wastewater.

\begin{tabular}{cccc}
\hline Level of Reaction Equation & Equation & Correlation Coefficient & Reaction Rate Constant \\
\hline Zero-order & $\mathrm{C}=-0.0012 \mathrm{t}+0.3258$ & $\mathrm{R}^{2}=0.8379$ & $1.2 \times 10^{-3}$ \\
First-order & $-\ln C=0.0046 \mathrm{t}+1.1203$ & $\mathrm{R}^{2}=0.8949$ & $4.6 \times 10^{-3}$ \\
Second-order & $1 / \mathrm{C}=0.0179 \mathrm{t}+3.046$ & $\mathrm{R}^{2}=0.9407$ & $1.8 \times 10^{-2}$ \\
Third-order & $1 / \mathrm{C}^{2}=0.142 \mathrm{t}+9.0079$ & $\mathrm{R}^{2}=0.9725$ & $1.4 \times 10^{-1}$ \\
\hline
\end{tabular}

In the equations: $C$ represents the COD concentration of refining wastewater after reaction time $t, g / L$; $\mathrm{t}$ represents the reaction time, $\min$.

From Table 3, when compared the correlation coefficient of zero-order, first order, second-order, and third-order reaction kinetics, we found the correlation coefficient of third-order reaction kinetics was the best with $\mathrm{R}^{2}=0.9725$. Thus, the process of multiple micro-electrolysis treated oil refinery wastewaters conformed to the third-order reaction kinetics, and the reaction rate constant was $1.4 \times 10^{-1}$.

\subsection{Continuous Running Experiment}

\subsubsection{Continuous Running Effect}

(1) The removal efficiency of pollutants. These experiments mainly studied the treatment effect of oil refinery wastewater by multiple micro-electrolysis under the optimum condition ( $\mathrm{pH} 3$, supporting electrolyte concentration was $0.05 \mathrm{~mol} / \mathrm{L}$, hydraulic retention time of $80 \mathrm{~min}$.) running continuously for 15 days. The running results are shown in Figure 9.

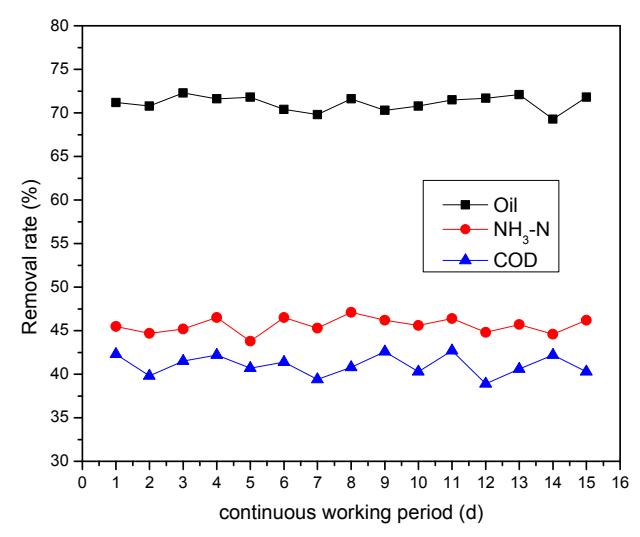

Figure 9. Removal efficiency of pollutants for continuous running.

Figure 9 showed, with continuous running for 15 days, the COD removal rate of effluent steady at $39.4 \%$ to $42.7 \%, \mathrm{NH}_{3}-\mathrm{N}$ removal rate steady at $43.8 \%$ to $46.5 \%$, oil removal rate steady at $69.3 \%$ to $72.3 \%$, and visible operation effect was stable. The regular filler was a metal alloy structured by high-temperature sintering, with a stable proportion of each component, and the contact between each composition was full. The regular alloy structure filler could ensure that the galvanic cell effect remained continuous and with high efficiency, and the separation of anode and cathode will not appear, 
like with physical mixing of the traditional filler [30]. The structure was formed with great specific surface area and uniform water circulation. The wastewater treatment provided a larger current density and better effect of catalytic reaction; the filler had a strong activity, and specific gravity was low, but lacked passivation and did not harden. The reaction rate was fast, and long-term operation was stable and effective.

(2) Biodegradability enhancement. Continuously working for 15 days, the water samples were taken at the inlet and outlet of the micro electrolysis reaction device and COD and $\mathrm{BOD}_{5}$ were determined; $\mathrm{B} / \mathrm{C}$ ratio were computed, and the change of $\mathrm{B} / \mathrm{C}$ ratio before and after micro-electrolysis reaction was studied. The results are shown in Figure 10.

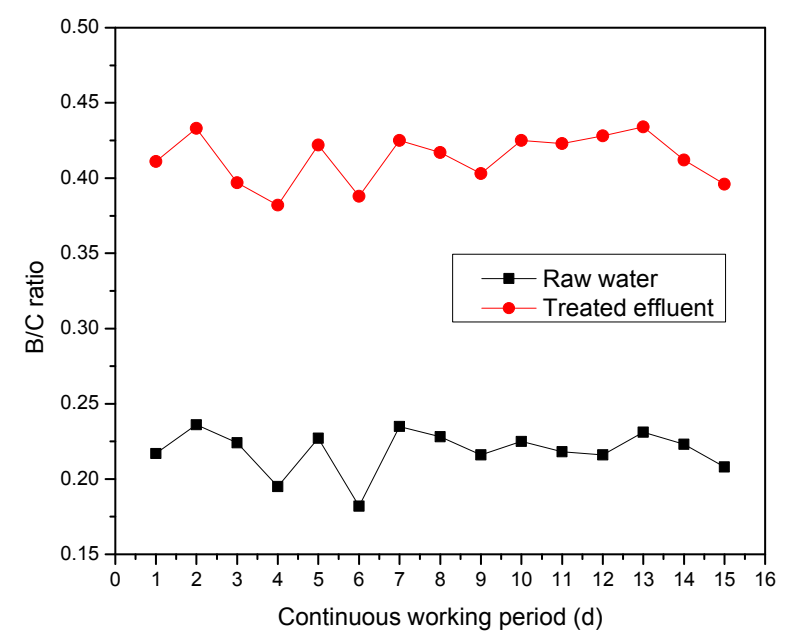

Figure 10. Comparison of $\mathrm{B} / \mathrm{C}$ ratios before and after micro-electrolysis treatment.

Figure 10 showed that the $B / C$ ratio of raw wastewater was 0.182 to 0.236 , through multiple micro-electrolysis treatments the $\mathrm{B} / \mathrm{C}$ ratio of effluent was steady at 0.382 to 0.434 , the average $\mathrm{B} / \mathrm{C}$ ratio of refining wastewater increased from 0.218 to $0.413, \mathrm{~B} / \mathrm{C}$ ratio increased to $89.4 \%$, benefit great to the subsequent biochemical treatment. There were two major reasons: on the one hand, a large number of ferrous ions were produced by anode and countless $(\mathrm{H})$ and $(\mathrm{OH})$ produced by cathode in the process of micro-electrolysis reaction, which could degrade the no biodegradable organic in oil refinery wastewater into small molecular and easily biodegradable organic, thus, it enhanced the biological availability; On the other hand, some refractory organics were adsorbed by the mix flocculation body of $\mathrm{Fe}(\mathrm{OH})_{2}, \mathrm{Fe}(\mathrm{OH})_{3}$ and $\mathrm{Al}(\mathrm{OH})_{3}$ and removed by co-precipitation in the flocculation sedimentation unit, thereby the hard biodegradable organic matter content in the wastewater was reduced. Visibly, multiple micro-electrolysis technology has obvious effect to improve the biological availability of oil refinery wastewater; pretreatment of the oil refinery wastewater with micro-electrolysis technology was advantageous to the enhancement of biochemical processing system [16].

\subsubsection{GC/MS Analysis of the Pollutions of Raw Wastewater and Effluent}

GC-MS has been known for its superior separation of complex organic compounds, greater sensitivity, and shorter measuring time [8,24]. Thus, it was used to detect and identify the organic compounds in the oil refinery wastewater. Figure 11a and Table 4 show the GC and the organic compound distribution of the oil refinery's wastewater. According to GC-MS analysis, the main organic compounds in the raw oil refinery's wastewater are phenol, phenol,3-methyl, 1-hexene,3,4-dimethyl, phenol,3,4-dimethyl, and other complex organic matter, which contribute to the COD value and pollute the environment. From Figure 11a,b, it can be seen clearly that the organic compounds in the effluents were obviously reduced, which indicated that 1-hexene,3,4-dimethyl, phenol, phenol,3-methyl, and phenol,3,4-dimethyl could be removed from the water by micro-electrolysis in varying degrees. 

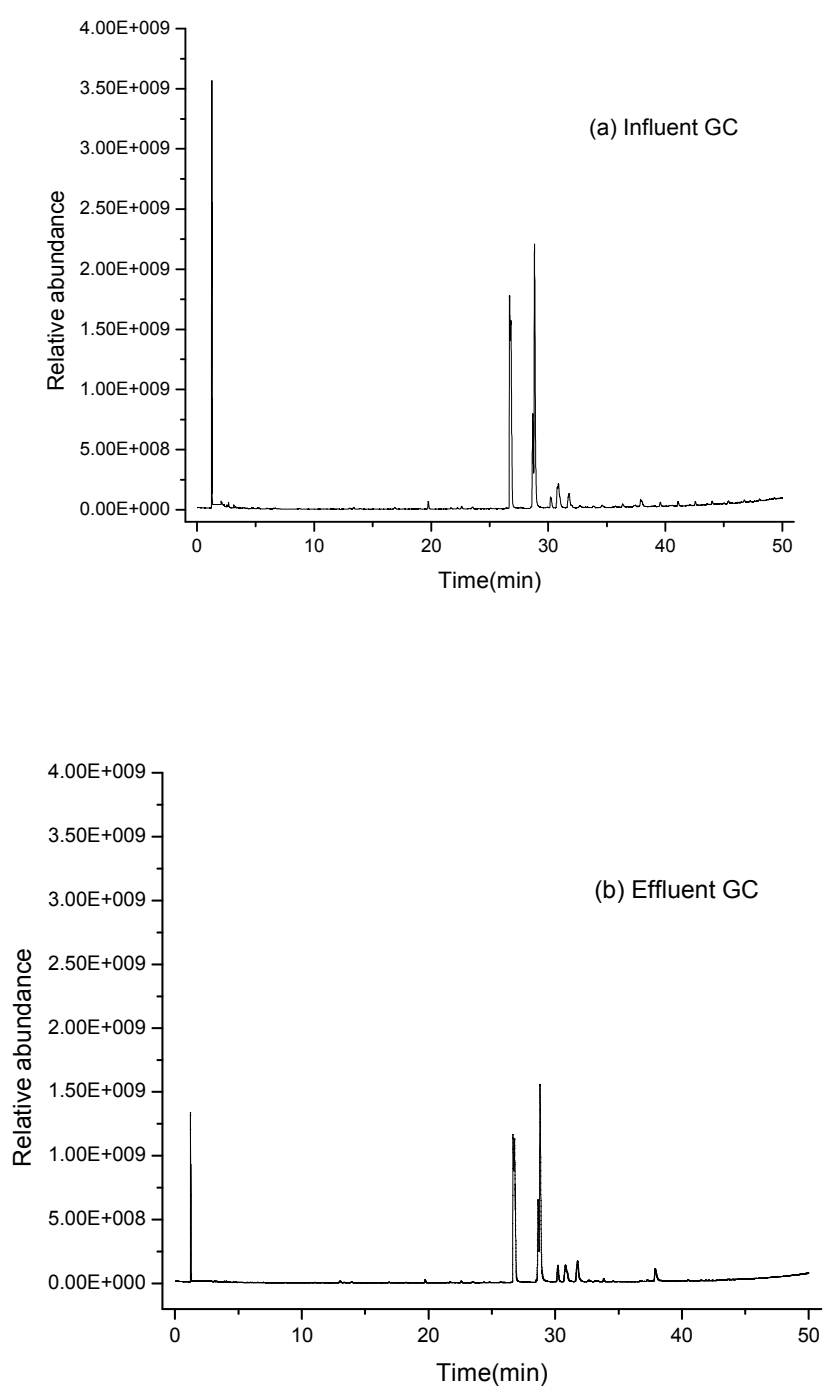

Figure 11. GC-MS chromatograms on dichloromethane extract from (a) influent and (b) effluent of the micro-electrolysis reactor.

Table 4. Main component distribution of the raw oil refinery wastewater.

\begin{tabular}{|c|c|c|c|c|c|c|}
\hline No. & $\begin{array}{l}\text { Retention Time } \\
(\text { min) }\end{array}$ & Compounds & $\begin{array}{l}\text { Molecular } \\
\text { Formula }\end{array}$ & $\begin{array}{l}\text { Proposed } \\
\text { Structures }\end{array}$ & $\begin{array}{c}\text { Possible } \\
(\%)\end{array}$ & $\begin{array}{c}\text { Area Percentage } \\
(\%)\end{array}$ \\
\hline 1 & 1.26 & 1-Hexene,3,4-dimethyl & $\mathrm{C}_{8} \mathrm{H}_{16}$ & & 31.49 & 13.73 \\
\hline 2 & 19.75 & Naphthalene & $\mathrm{C}_{10} \mathrm{H}_{8}$ & & 24.4 & 0.64 \\
\hline 3 & 26.70 & Phenol & $\mathrm{C}_{6} \mathrm{H}_{6} \mathrm{O}$ & & 42.64 & 34.19 \\
\hline 4 & 28.83 & Phenol,3-methyl & $\mathrm{C}_{7} \mathrm{H}_{8} \mathrm{O}$ & & 62.43 & 26.17 \\
\hline 5 & 30.87 & Phenol,3,4-dimethyl & $\mathrm{C}_{8} \mathrm{H}_{10} \mathrm{O}$ & & 34.67 & 8.01 \\
\hline 6 & & Other org & ic compounds & & & 17.26 \\
\hline
\end{tabular}




\subsubsection{UV-VIS Spectral of the Degradation Process}

Petroleum and its products have characteristic absorption in the ultraviolet region. The main absorption wavelength of aromatic compounds with a benzene ring is $250-260 \mathrm{~nm}$; the mainly-absorbed wavelength of compounds with conjugated double bonds is $215-235 \mathrm{~nm}$. Figure 12 indicates that there are two obvious characteristic absorption peaks in the ultraviolet absorption spectrum of raw water in the wavelength of $215-235 \mathrm{~nm}$ and $250-260 \mathrm{~nm}$. As the reaction proceeded, wastewater at each wavelength absorbance reduced which indicated that the concentration of organic matter in the wastewater decreased, but not obviously, and led to the COD removal rate of oil refinery wastewater treatment being only about $40 \%$. In order to improve the efficiency of micro-electrolysis technology for refinery sewage treatment, on the one hand, more effective multiple micro-electrolysis fillers need to be developed while, on the other hand, micro-electrolysis technology or combination with other process also need to be strengthened.

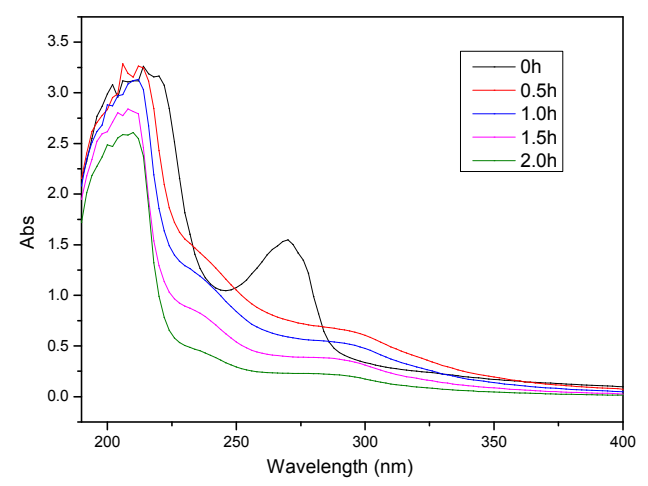

Figure 12. UV-VIS spectral change of oil refinery wastewater with different degradation times.

\subsubsection{The Comparison of the Filler Change before and after Using}

The S-4800 II FE-SEM (FE-SEM, $30 \mathrm{kV}$, Hitachi, Tokyo, Japan) was used to observe the morphologies of fillers before and after using, the results are shown in Figure 13.

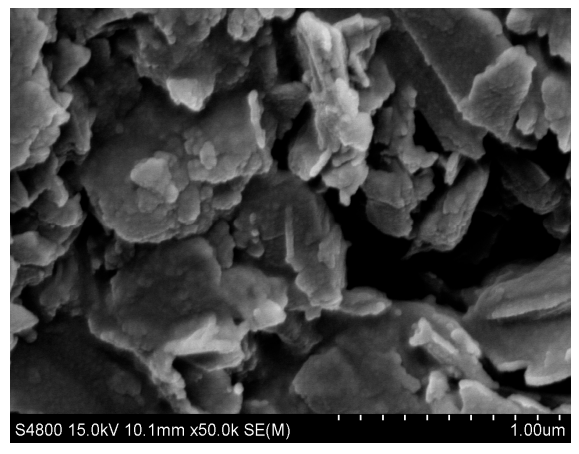

(a) SEM figure of filler before using

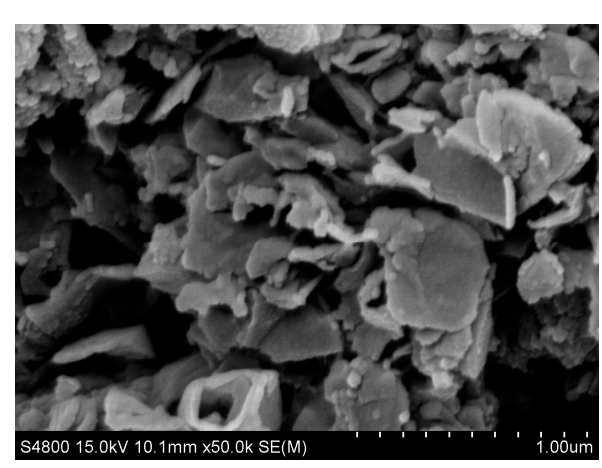

(b) SEM figure of filler after 15 days' using

Figure 13. SEM contrast figure of filler before and after using. (a) SEM figure of filler before using and (b) SEM figure of filler after 15 days' use.

Figure 13 shows a SEM contrast figure of the filler before and after use. Comparing Figure 13b with Figure 13a, the morphology of the filler saw no significant change after 15 days' use. The pore shape of the filler was intact, no jam phenomenon occurred, which showed that the alloy structure of the filler had high strength, good physical structure, and running wear resistance in the process of consumption, ensuring that the galvanic effect was continuously high. Thus, the quality of effluent was stable and the usable life was long. 


\subsection{Reaction Mechanism of Multiple Micro-Electrolysis}

Fe and activated carbon can form galvanic cells in electrolyte solution $[20,23]$. The electrode reaction can be presented as follows:

$$
\begin{gathered}
\text { Anode }: \mathrm{Fe}-2 \mathrm{e} \rightarrow \mathrm{Fe}^{2+} ; \mathrm{E}^{\Theta}\left(\mathrm{Fe}^{2+} / \mathrm{Fe}\right)=-0.44 \mathrm{~V} \\
\text { Cathode }: 2 \mathrm{H}^{+}+2 \mathrm{e} \rightarrow 2[\mathrm{H}] \rightarrow \mathrm{H}_{2} \uparrow ; \mathrm{E}^{\Theta}\left(\mathrm{H}^{+} / \mathrm{H}_{2}\right)=0.00 \mathrm{~V} \text { (Acidic) }
\end{gathered}
$$

When $\mathrm{Al}$ powder is added to the system, which also can form galvanic cells with activated carbon, the electrode reaction can be presented as follows [12]:

$$
\begin{gathered}
\text { Anode }: \mathrm{Al}-3 \mathrm{e} \rightarrow \mathrm{Al}^{3+} ; \mathrm{E}^{\Theta}\left(\mathrm{Al}^{3+} / \mathrm{Al}\right)=-1.66 \mathrm{~V} \\
\text { Cathode }: 2 \mathrm{H}^{+}+2 \mathrm{e} \rightarrow 2[\mathrm{H}] \rightarrow \mathrm{H}_{2} \uparrow ; \mathrm{E}^{\Theta}\left(\mathrm{H}^{+} / \mathrm{H}_{2}\right)=0.00 \mathrm{~V} \text { (Acid) }
\end{gathered}
$$

As can be seen from the above electrode reaction, in multiple micro-electrolysis systems Fe and $\mathrm{C}$ could form micro-batteries, $\mathrm{Al}$ and $\mathrm{C}$ could also form micro-batteries, and the conductivity of $\mathrm{Al}$ was superior to promote galvanic cell reaction. In multiple micro-electrolysis systems, $\mathrm{Al}$ and $\mathrm{Fe}$ constituted a bimetal catalytic system and improved the efficiency of the catalytic degradation reaction; the sediment of $\mathrm{Fe}$ and $\mathrm{Al}$ can form the synergy flocculation and settleability. Figure 14 shows the schematic diagram of the reaction mechanism of $\mathrm{Fe} / \mathrm{Al} / \mathrm{C}$ multiple micro-electrolysis.

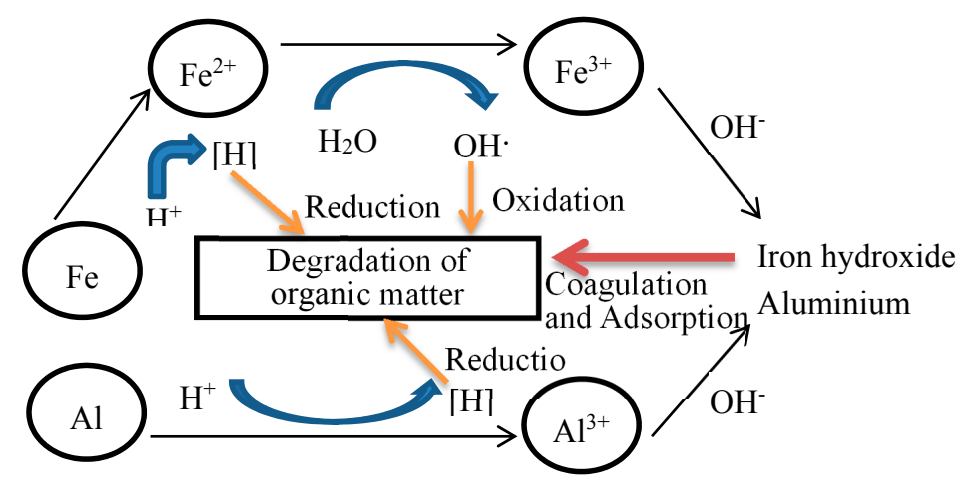

Figure 14. The reaction mechanism of $\mathrm{Fe} / \mathrm{Al} / \mathrm{C}$ multiple micro-electrolysis.

As shown in Figure 14, in Fe/ $\mathrm{Al} / \mathrm{C}$ multiple micro-electrolysis system reactions, on the one hand, the anode reaction produced the new ecological bivalent iron ion which had strong reducing power, which could graduate part of the refractory ring and long chain organic into easily biodegradable small molecules of organic matter; the cathode reaction produced a large number of new ecological $(\mathrm{H})$ and $(\mathrm{OH})$, and could also react with many organic component of the wastewater. This resulted in organic macromolecular chain scission and decomposition to small-molecule organic matter. On the other hand, $\mathrm{Fe}^{2+}, \mathrm{Fe}^{3+}$, and $\mathrm{A1}^{3+}$ generated in the reaction, under alkaline $\mathrm{pH}$ of 9-10, could form $\mathrm{Fe}(\mathrm{OH})_{2}, \mathrm{Fe}(\mathrm{OH})_{3}$, and $\mathrm{Al}(\mathrm{OH})_{3}$. The synergy of $\mathrm{Fe}(\mathrm{OH})_{2}, \mathrm{Fe}(\mathrm{OH})_{3}$, and $\mathrm{Al}(\mathrm{OH})_{3}$ made the flocculation and settleability, which was superior to pure $\mathrm{Fe}(\mathrm{OH})_{2}$ and $\mathrm{Fe}(\mathrm{OH})_{3}$. Therefore, added $\mathrm{Al}$ could improve the removal efficiency of $\mathrm{COD}$, but the $\mathrm{Al}$ additive quantity should not excessive, because the corrosion of aluminum in $\mathrm{Fe} / \mathrm{Al}$ battery reactions can inhibit the corrosion of iron, thereby reducing the generation of ferrous ion.

\section{Conclusions}

(1) Al was determined as the adding metal composition of the micro-electrolysis filler, to constitute $\mathrm{Fe} / \mathrm{C} / \mathrm{Al}$ multiple micro-electrolytic systems. The new regular $\mathrm{Fe} / \mathrm{C} / \mathrm{Al}$ multiple micro-electrolysis filler was prepared, which was a granular structure of the metal alloy, and the optimum $\mathrm{m}(\mathrm{Fe} / \mathrm{C} / \mathrm{Al})$ was 3:1:1. 
(2) The application effect of oil refinery wastewater pretreatment by $\mathrm{Fe} / \mathrm{C} / \mathrm{Al}$ multiple micro-electrolysis was remarkable. The optimum process parameters of $\mathrm{pH} 3$, reaction time $80 \mathrm{~min}$, $\mathrm{Na}_{2} \mathrm{SO}_{4}$ additive concentration $0.05 \mathrm{~mol} / \mathrm{L}$.

(3) When continuously running for 15 days, the $\mathrm{COD}, \mathrm{NH}_{3}-\mathrm{N}$, and oil removal rate were stable, the average $\mathrm{B} / \mathrm{C}$ ratio of wastewater increased from 0.218 to 0.413 , and the biodegradability of the wastewater had remarkably improved.

This study shows that the Fe/C/Al multiple micro-electrolysis can be considered as an effective and robust method for oil refinery wastewater pretreatment.

Acknowledgments: Financial support for this research was provided by the Key Natural Science Foundation, transformation mechanism and control principle of nitrogenous pollutant in the urban water supply system (Grant No. 51438006), the National Key Scientific Instrument and Equipment Development Project (Grant No. 2014YQ060773). This work also supported by 948 Projects of Ministry of Water Resources, trace determination of volatile organic compound in water, and the Priority Academic Program Development of Jiangsu Higher Education Institutions.

Author Contributions: Ruihong Yang and Jianzhong ZHU conceived and designed the study. Ruihong Yang performed the experiments and wrote the paper. Yingliu Li and Hui Zhang reviewed and edited the manuscript. All authors read and approved the manuscript.

Conflicts of Interest: I, Ruihong Yang, author of the paper referenced above, have no financial and personal relationships with other people or organizations that could inappropriately influence (bias) this work.

\section{References}

1. Yuliwati, E.; Ismail, A.F. Effect of additives concentration on the surface properties and performance of PVDF ultrafiltration membranes for refinery produced wastewater treatment. Desalination 2011, 273, $226-234$. [CrossRef]

2. Yuliwati, E.; Ismail, A.F.; Lau, W.J.; Ng, B.C.; Mataram, A.; Kassim, M.A. Effects of process conditions in submerged ultrafiltration for refinery wastewater treatment: Optimization of operating process by response surface methodology. Desalination 2012, 287, 350-361. [CrossRef]

3. Wang, Y.; Wang, Q.H.; Li, M.; Yang, Y.N.; He, W.; Yan, G.X.; Guo, S.H. An alternative anaerobic treatment process for treatment of heavy oil refinery wastewater containing polar organics. Biochem. Eng. J. 2016, 105, 44-51. [CrossRef]

4. Rastegar, S.O.; Mousavi, S.M.; Shojaosadati, S.A.; Sheibani, S. Optimization of petroleum refinery effluent treatment in a UASB reactor using response surface methodology. J. Hazard. Mater. 2011, 197, $26-32$. [CrossRef] [PubMed]

5. Nasirpour, N.; Mousavi, S.; Shojaosadati, S. Biodegradation potential of hydrocarbons in petroleum refinery effluents using a continuous anaerobic-aerobic hybrid system. Korean J. Chem. Eng. 2015, 32, 874-881. [CrossRef]

6. Sere, Z.; Maravi, N.; Taka, A.; Nikoli, I.; Dragana, S.S.; Joki, A.; Hodur, C. Treatment of vegetable oil refinery wastewater using alumina ceramic membrane: Optimization using response surface methodology. J. Clean. Prod. 2016, 112, 3132-3137. [CrossRef]

7. Yavuz, Y.; Koparal, A.S.; Öğütveren, Ü.B. Treatment of petroleum refinery wastewater by electrochemical methods. Desalination 2010, 258, 201-205. [CrossRef]

8. Yan, L.; Ma, H.Z.; Wang, B.; Mao, W.; Chen, Y.S. Advanced purification of petroleum refinery wastewater by catalytic vacuum distillation. J. Hazard. Mater. 2010, 178, 1120-1124. [CrossRef] [PubMed]

9. Abdelwahab, O.; Amin, N.K.; El-Ashtoukhy, E.-S.Z. Electrochemical removal of phenol from oil refinery wastewater. J. Hazard Mater. 2009, 163, 711-716. [CrossRef] [PubMed]

10. Rasheed, Q.J.; Pandian, K.; Muthukumar, K. Treatment of petroleum refinery wastewater by ultrasound-dispersed nanoscale zero-valent iron particles. Ultrason. Sonochem. 2011, 18, 1138-1142. [CrossRef] [PubMed]

11. Liu, X.L.; Wen, J.P.; Yuan, Q.; Zhao, X.M. The pilot study for oil refinery wastewater treatment using a gas-liquid-solid three-phase flow airlift loop bioreactor. Biochem. Eng. J. 2005, 27, 40-44.

12. Shariati, S.R.P.; Bonakdarpour, B.; Zare, N.; Ashtiani, F.Z. The effect of hydraulic retention time on the performance and fouling characteristics of membrane sequencing batch reactors used for the treatment of synthetic petroleum refinery wastewater. Bioresour. Technol. 2011, 102, 7692-7699. [CrossRef] [PubMed] 
13. Santo, C.E.; Vilar, V.J.P.; Botelho, C.M.S.; Bhatnagar, A.; Kumar, E.; Boaventura, R.A.R. Optimization of coagulation-flocculation and flotation parameters for the of a petroleum refinery effluent from a Portuguese plant treatment. Chem. Eng. J. 2012, 183, 117-123. [CrossRef]

14. Wei, L.Y.; Guo, S.H.; Yan, G.X.; Chen, C.M.; Jiang, X.Y. Electrochemical pretreatment of heavy oil refinery wastewater using a three-dimensional electrode reactor. Electrochimica Acta 2010, 55, 8615-8620. [CrossRef]

15. Saien, J.; Nejati, H. Enhanced photocatalytic degradation of pollutants in petroleum refinery wastewater under mild conditions. J. Hazard. Mater. 2007, 148, 491-495. [CrossRef] [PubMed]

16. Ma, L.M. Enhanced biological treatment of industrial wastewater with bimetallic zero-valent iron. Environ. Sci. Technol. 2008, 42, 5384-5389. [CrossRef] [PubMed]

17. Chen, C.; Wei, L.; Guo, X.; Guo, S.; Yan, G. Investigation of heavy oil refinery wastewater treatment by integrated ozone and activated carbon-supported manganese oxides. Fuel Process. Technol. 2014, 124, 165-173. [CrossRef]

18. Zhu, Q.S.; Guo, S.H.; Guo, C.M.; Dai, D.; Jiao, X.K.; Ma, T.Q.; Chen, J.F. Stability of Fe-C micro-electrolysis and biological process in treating ultra-high concentration organic wastewater. Chem. Eng. J. 2014, 255, 535-540. [CrossRef]

19. Ning, X.A.; Wen, W.B.; Zhang, Y.P.; Li, R.J.; Sun, J.; Wang, Y.J.; Yang, Z.Y.; Liu, J.Y. Enhanced dewaterability of textile dyeing sludge using microelectrolysis pretreatment. J. Environ. Manag. 2015, 161, 181-187. [CrossRef] [PubMed]

20. Zhang, X.B.; Dong, W.Y.; Sun, F.Y.; Yang, W.; Dong, J. Degradation efficiency and mechanism of azo dye RR2 by a novel ozone aerated internal micro-electrolysis filter. J. Hazard. Mater. 2014, 276, 77-87. [CrossRef] [PubMed]

21. Qi, Y.F.; He, S.B.; Wu, S.Q.; Dai, B.B.; Hu, C.H. Utilization of micro-electrolysis, up-flow anaerobic sludge bed, anoxic/oxic-activated sludge process, and biological aerated filter in penicillin $\mathrm{G}$ wastewater treatment. Desalination Water Treat. 2015, 55, 1480-1487. [CrossRef]

22. Lv, Y.L.; Wang, Y.Q.; Shan, M.J.; Shen, X.; Su, Y. Denitrification of coking wastewater with micro-electrolysis. J. Environ. Sci. 2011, 23, S128-S131. [CrossRef]

23. Liu, W.W.; Tu, X.Y.; Wang, X.P.; Wang, F.Q.; Li, W. Pretreatment of coking wastewater by acid out, micro-electrolysis process with in situ electrochemical per-oxidation reaction. Chem. Eng. J. 2012, 200-202, 720-728. [CrossRef]

24. Lai, B.; Zhou, Y.X.; Qin, H.K.; Wu, C.Y.; Pang, C.C.; Yu, L.; Xu, J.X. Pretreatment of wastewater from acrylonitrile-butadiene-styrene (ABS) resin manufacturing by micro-electrolysis. Chem. Eng. J. 2012, 179, 1-7. [CrossRef]

25. Yang, X.Y.; Xue, Y.; Wang, W.N. Mechanism, kinetics and application studies on enhanced activated sludge by interior micro-electrolysis. Bioresour. Technol. 2009, 100, 649-665. [CrossRef] [PubMed]

26. Sun, L.; Wang, C.; Ji, M.; Kong, X. Treatment of mixed chemical wastewater and the agglomeration mechanism via an internal electrolysis filter. Chem. Eng. J. 2013, 215-216, 50-56. [CrossRef]

27. Qin, S.L.; Li, X.D.; Zhang, T.; Rong, W.G. Pretreatment of chemical cleaning wastewater by micro-electrolysis process. Procedia Environ. Sci. 2011, 10, 1154-1158. [CrossRef]

28. Huang, L.H.; Sun, G.P.; Yang, T.; Zhang, B.; He, Y.; Wang, X.H. A preliminary study of anaerobic treatment coupled with micro-electrolysis for anthraquinone dye wastewater. Desalination 2013, 309, 91-96. [CrossRef]

29. Qin, L.; Zhang, G.L.; Meng, Q.; Xu, L.S.; Lv, B.S. Enhanced MBR by internal micro-electrolysis for degradation of anthraquinone dye wastewater. Chem. Eng. J. 2012, 210, 575-584. [CrossRef]

30. Qin, S.L.; Zhao, Y.Y.; Wang, Z.Q. Existing problems and improvement measures of micro-electrolysis process and conventional filler. Energy Environ. Prot. 2013, 27, 8-10.

31. Qi, W.Q. Aggregative indicator and inorganic pollutant. In Water and Exhausted Water Monitoring Analysis Method; Wei, F.S., Qi, W.Q., Eds.; China Environmental Science Press: Beijing, China, 2006; pp. 276-284.

32. Geng, W. Fatty acid analysis of papaya seed by external standard method and peak area normalization method. Chem. Eng. 2015, 1, 23-24.

(C) 2016 by the authors; licensee MDPI, Basel, Switzerland. This article is an open access article distributed under the terms and conditions of the Creative Commons Attribution (CC-BY) license (http://creativecommons.org/licenses/by/4.0/). 